\title{
Teaching Phrasal Verbs More Efficiently: Using Corpus Studies and Cognitive Linguistics to Create a Particle List
}

Ryan Spring*

Tohoku University, Sendai City, Aoba-ku, Kawauchi 41, Japan

Corresponding Author: Ryan Spring, E-mail: spring.ryan.edward.c4@tohoku.ac.jp

The research is financed by the Japan Society for the Promotion of Science, project number 16K16868

\begin{tabular}{|c|c|}
\hline E INFO & ABSTRACT \\
\hline Article history & \multirow{9}{*}{$\begin{array}{l}\text { Phrasal verbs are important for EFL and ESL education because of their high frequency, but } \\
\text { can be difficult for learners because of their number and polysemy. While there are a number } \\
\text { of studies on phrasal verbs, the widening focus of such studies has left a gap between theory } \\
\text { and practical instruction. This study improves upon previous studies related to teaching phrasal } \\
\text { verbs through cognitive linguistics by combining the theory of event conflation with corpus- } \\
\text { based research to create a list of phrasal verb particles and meanings that is concise and yet } \\
\text { comprehensive enough to account for approximately } 95 \% \text { of common phrasal verb meanings. It } \\
\text { also reports the results of an experiment in which learners taught with this particle list improved } \\
\text { more on pre-/post-tests of phrasal verbs than learners that studied a list of the most common } \\
\text { phrasal verbs as whole entities ( } p<0.001, d=1.34) \text {. Quantitative and qualitative data presented } \\
\text { in this study also indicate that learners taught with the particle list improved their ability to } \\
\text { conjecture the meanings of novel phrasal verbs more effectively than learners who studied } \\
\text { common phrasal verbs as whole units. }\end{array}$} \\
\hline Received: May 10, 2018 & \\
\hline 1: August & \\
\hline d: October 31, 2018 & \\
\hline Volume: 9 Issue: 5 & \\
\hline Advance access: August 2018 & \\
\hline interest: None & \\
\hline Funding: JSPS & \\
\hline & \\
\hline
\end{tabular}

Phrasal Verbs,

Cognitive Linguistics,

Corpus,

Instruction Materials,

TEFL,

Second Language Acquisition

\section{INTRODUCTION}

Though phrasal verbs ${ }^{1}$ (henceforth PVs) are important for EFL and ESL learners because of their high frequency, they are notoriously difficulty to learn, which often causes learners to avoid studying and using them (Liao and Fukuya, 2004; Jahedi and Mukundan, 2015; etc.). There have been many studies conducted on PV education, and can be generally categorized as: analysis of the syntactic and semantic properties of PVs, comparative analysis of non-native learners' avoidance of PVs, analysis of ESL learner corpora in comparison with native learner corpora, and corpus-based analysis of PVs in language teaching materials (Jahedi and Mukundan, 2015: 161 $)^{2}$. However, there are few studies that attempt to straddle these different areas of research to offer a wider, more beneficial guide to PVs for learners and educators. For example, studies such as Gardner and Davies (2007) and Garnier and Schmitt (2015) offer learners and instructors lists of the most common PVs, which are surely important as a guide for which PVs to study first, but teaching methods and instruction are outside of the scope of their work. Thus, even if a learner were to obtain such a list, there is the strong possibility that they would simply attempt to learn the PVs by memorizing them as whole units. However, as pointed out by Side (1990) and Lee (2012), studying PVs in parts, focusing on the particles, seems to be a more effective way to learn them. Though Side (1990) and Lee (2012) are promising studies, both studies only focused on three PV particles, which covers a very limited number of PVs. This paper thus attempts to advance the ideas of Side (1990) and Lee (2012) by using corpus studies, such as Garnier and Schmitt (2015), and cognitive linguistic theory to create a comprehensive list of PV particles that learners can utilize to study a wide range of PVs more effectively. It focuses on the following research questions: (1) Can cognitive linguistic research be combined with corpus studies of PVs to create a concise and comprehensive list of PV particles and their meanings? (2) Is studying PVs through a list of particle meanings more effective than learning PVs as whole units?

\section{REVIEW OF THE LITERATURE}

While much of the research surrounding PVs focuses on analyses of PVs themselves (Jahedi and Mukandan, 2015), other researchers have more recently attempted to offer insight into 
how PVs and their meanings are constructed to make them easier for learners to remember (Side, 1990; Lee, 2012; Yasuda, 2010; etc.). However, many of these studies generally focus on specific PVs and are not aimed at addressing the whole of PVs. For example, Side (1990) indicates that there are problems with memorizing PVs as whole units, such as the fact that most PVs have multiple meanings and the particles seem to be random, and then suggests that many PVs are formed by analogy with existing PVs. However, his research only covers three particles and does not offer any theoretical reasons as to why the particles have the meanings that they do. Other notable attempts to explain PV formation in a way that is more beneficial to learners include Yasuda (2010) and Lee (2012). Lee's (2012) study provided quantitative and qualitative data suggesting that cognitive-linguistic inspired instruction of PV particles helped to improve the learning of PVs, but focused only on PVs containing the particles up, out and over. Yasuda (2010) reported on lessons that utilized cognitive linguistics (i.e. metaphor theory) to help explain PVs to Japanese EFL learners, offering qualitative and quantitative data to suggest that their learning was enhanced through such explanations. Her study mostly focused on metaphoric extension and the idiomatic expression of PVs, which have been shown to enhance vocabulary retention (Boers, 2000), and offers promising results, but was similarly limited in that it only focuses on twenty PVs.

The aforementioned studies suggest that teaching PVs through cognitive linguistic theory and by focusing on particle meaning aids learners, but do not cover a wide range of PVs and thus can potentially be expanded upon by being combined with corpus studies of the most common PVs (e.g. Garnier \& Schmitt, 2015; etc.) to create a PV particle list that can be used to teach a wider range of PVs while focusing on particle meaning. The list would need to not only include the particles, but also provide a wide variety of meanings for each without being so verbose that it becomes cumbersome for learners. To this end, this study utilizes Talmy's (1985) cognitive linguistic theory of event conflation to create the list of meanings for PV particles because of its range, explanatory power, and the large number of SLA studies that suggest its importance in EFL/ESL education.

Event conflation has a very large scope and can thus be used to explain a wide range of PVs. The theory suggests that two events can be thought of and expressed as a single event. For example, the sentence 'Jack skipped across the park' contains both the information that (i) Jack was skipping and that (ii) Jack travelled from one end of the park to the other, but these two actions are introduced as one single event. According to Talmy (1985), this phenomenon occurs in every language, but in different ways. In English, it is generally done through the use of a verb that tells the coevent, i.e. what is happening or why/how it is happening, and a satellite ${ }^{3}$ that tells the main-event, i.e. the change or final result of the action. In the example sentence, the fact that Jack was skipping is communicated through the verb skip, and the change from one location to another is communicated through the satellite across. While Talmy (1985, 2000,2009 ) argues that satellites can be prepositions, particles, or adjectives in English, and thus the total scope of event conflation is beyond that of PVs, the example sentence given indicates that PVs are indeed contained within this theoretical construct (i.e. the two events are conflated into the PV skip across), and this wide scope allows it to be used to explain many different PV particles. PVs can then be explained as being a combination of two separate meanings - one coming from the meaning of the verb (i.e. the co-event) and one coming from the particle (i.e. the main event). This can be applied to a wide variety of both common and uncommon PVs. For example, considering the fact that the word out can have the meaning of 'to exit', a large number of PVs that contain out can be easily explained, such as: walk out, run out, sprint out, fly out, whoosh out, etc. In each of these PVs, the word out retains its meaning of 'to exit' and the verb simply gives detailed information as to how the object was exiting (or what it was doing while exiting). As there are many manner of motion verbs in English (e.g. walk, run, sprint, dash, whoosh, zoom) and they can generally combine with out to create a similar meaning, it would seem that many generative PVs follow this pattern. For this reason, event conflation could also help such learners to conjecture the meanings of novel PVs. As Side (1990) points out, native English speakers are able to understand most novel PVs, and thus there must be some mechanism by which they conjecture the meanings from knowledge of PV particles and how they combine with verbs to create new meanings. The theory of event conflation can aide learners in this respect by offering them an explanation that can help them to foster a similar mechanism and consequently improve their ability to conjecture the meanings of novel PVs much in the same way.

The theory of event conflation can also explain much of the polysemy found in PVs. Talmy $(1985,2000)$ suggests that there are 5 types of events in which conflation occurs: motion, change of state, realization of goals, aspect and correlation of actions. Examples of PVs fulfilling these roles in English can be found below (with italics to emphasize the PVs):

1. Motion: Jack skipped across the park.

2. Change of state: Jack tied together the boxes.

3. Realization of goals: Jack chased down the criminal.

4. Aspect: Jack ran on, even though he was tired and wanted to quit.

5. Correlation of actions: Jack sang along with the radio.

Though PVs often have a number of meanings, this can be explained by the fact that the particles themselves have several meanings, i.e. those posited by the theory of event conflation, exemplified above. For example, the two most common meanings of look up are 'to physically look upward' and 'to research or investigate'. The former meaning can be explained as a motion event in which the verb, look, tells how or what it is that is moving (i.e. one's line of vision), and up indicates in which direction. The latter meaning can be explained as a realization of goal event in which, the verb, look, tells what is happening, and up indicates that the goal of the verb look (i.e. finding what one is looking for) is being realized. In this case, look up takes the meaning of to 'look until completion' or to 'look to a proper degree' (i.e. until one has the information one desires). 
Teaching PVs through event conflation also has several pedagogical benefits. For example, it allows for multiple particle meanings to be explained through metaphoric extensions of their other meanings, which has been noted to aide in memorization (Yasuda, 2010; Boers, 2000). One such metaphoric extension comes from the inherent connection between motion and change of state events (the first two event types given above). As noted by Talmy (1985, 2000), both are types of transitions: change being a transition from one state of being to another, and motion being a transition from one location to another. For example, back has both a motion and a change meaning, the former being to return to the original place and the latter being to return to the original state of being. For a more complex example, let us consider the various meanings of out, which has a motion meaning of 'to exit', and a general change meaning of 'to disappear'. While the two might seem unrelated at first glance, the change meaning can be explained with the metaphor out of sight, out of mind. If something moves to a location where it can no longer be seen (e.g. outside or out of view), it has for all intents and purposes disappeared. Interestingly, out can also exhibit the opposite meaning (to appear) depending on the verb that it is coupled with. Though this might seem like a contradiction, it is not if we consider the inherent relationship between the speaker and the object in motion or transition. For example, the word go indicates that something is moving further away from the speaker, and thus in the example of go out, the object would exit, leaving the speaker behind where they could no longer see it. Thus, when go out takes a change meaning, it becomes 'to disappear', as in 'the lights went out'. Conversely, the word come indicates that something is moving closer to the speaker. In a motion event, something that comes out would thus be moving towards the speaker, initially invisible to the speaker (as initially the exiting entity would have to be inside, while the speaker would have to be outside) and would then become visible as it exits and joins the speaker outside. Since an object that is coming out would thus move from an invisible (and thus out of mind) area to a visible one, the change meanings of come out becomes 'to appear', as in 'his secret came out'. Out also provides a good example of how its other meaning (realization of goals, as per Talmy, 2000) is a metaphoric extension of its change meaning. This is because when out takes this meaning, it generally indicates that something has disappeared as a result of the realization. For example, in miss out, someone has missed something completely, and there are no more chances, and in sell out, something has been sold completely, and there is no more of the item available.

Finally, several SLA studies have pointed to the fact that Talmy (2000) claims that a typology is possible based on how languages generally conflate events, and have shown that learners with L1s such as Japanese (verb-framed languages) tend to have extreme difficulty acquiring the patterns of L2s of a different type (satellite-framed languages) such as English (Inagaki, 2002; Spring \& Horie, 2013; Spring, 2015; etc.). For example, Inagaki (2002) showed that L1 Japanese learners of English often confuse motion expressions for location expressions in L2 English. Furthermore,
Spring and Horie (2013) showed that L1 Japanese learners of English are generally unable to combine manner of motion verbs with particles to create motion expressions, and Spring (2015) showed that L1 Japanese learners of English have similar difficulties in understanding and producing change of state expressions in L2 English. These studies all suggest that teaching L1 Japanese learners motion and change of state events expressions through event conflation might be helpful for them, although the scope of such studies rests solely in showing the differences and difficulties such learners have.

Given the adaptability, explanatory power and pedagogical implications of using event conflation to teach PVs, as described above, it follows that it could be combined with PV list studies (e.g. Garnier and Schmitt, 2015; Liu, 2011; etc.) to create a comprehensive list of PV particles and their meanings that would be useful for learners.

\section{CREATING A PV PARTICLE LIST}

In order to create a list of PV particles and their meanings based on Talmy's $(1985,2000)$ theory of event conflation and corpus research, I first extracted a list of all of the particles that appear in Garnier and Schmitt's (2015) list of the most common 150 PVs. The meaning senses of these particles were then created utilizing the theory of event conflation, such as with the example of out, given in the previous section. This process was repeated for each extracted particle, and then condensed for conciseness. In creating the list, I found that most particle meanings correspond to either motion or change of state events, and that of the particles that appear in PVs in Garnier and Schmitt's (2015) list, only three take realization of goals event meanings (up, down and out), only one takes an aspect event meaning (on) and only one takes a correlation of action event meaning (along). Since there is no overlap amongst the particles in the final three categories, I combined them into one all-encompassing category for conciseness (renamed time-related). The final list of particle meanings is shown in Table 1, with representative examples of PVs for each. It is concise enough to contain only 17 particles ( 15 with motion meanings, ten with change meanings, and five with other types of meanings), while being comprehensive enough to be able to explain approximately $95 \%$ of the two most common meanings of the 150 most common PVs as given by Garnier and Schmitt (2015)

As indicated in the previous section, studies such as Side (1990) and Lee (2012) suggest that learning PVs in parts, focusing on particle meaning, is more effective than learning them as whole units. Therefore, it follows that using the comprehensive PV particle list given in Table 1 to learn PVs would be more effective than learning them as whole units from a PV list. Though the list does not account for all meanings of all PVs, it does account for a large majority of them (see Note 4) while having far fewer meaning tokens to remember than a list of common PVs (there are only 30 meaning tokens to remember versus several hundred for Garnier \& Schmitt's PHaVE list). Furthermore, studies such as Spring and Horie (2013), Inagaki (2002) and Spring (2015) suggest that since the list given in Table 1 was created 
Table 1. List of particle meanings condensed into three categories

\begin{tabular}{|c|c|c|c|}
\hline Particle & Motion Meaning & Change Meaning & Time-Related \\
\hline up & $\begin{array}{l}\text { Move from a low position to a higher } \\
\text { position (jump up, stand up, fly up) }\end{array}$ & $\begin{array}{l}\text { Become higher/ better/more } \\
\text { (go up, pile up, work up) }\end{array}$ & $\begin{array}{l}\text { Do completely, properly, } 100 \% \\
\text { - generally with a positive } \\
\text { meaning (clean up, dress up, } \\
\text { charge up) }\end{array}$ \\
\hline down & $\begin{array}{l}\text { Move from a high position to a lower } \\
\text { position (sit down, lay down, fall down) }\end{array}$ & $\begin{array}{l}\text { Become lower/bad/ worse/ } \\
\text { less (let down, come down, } \\
\text { run down) }\end{array}$ & $\begin{array}{l}\text { Finish, achieve a goal - often } \\
\text { with a negative meaning or } \\
\text { downward image (break down, } \\
\text { close down, hunt down) }\end{array}$ \\
\hline in & Enter (go in, come in, walk in) & & \\
\hline out & Exit (go out, walk out, fly out) & $\begin{array}{l}\text { (1) Disappear (go out, turn } \\
\text { out, burn out) } \\
\text { (2) Appear (come out, jump } \\
\text { out) }\end{array}$ & $\begin{array}{l}\text { Do completely - and something } \\
\text { has disappeared (sell out, miss } \\
\text { out, find out) }\end{array}$ \\
\hline on & $\begin{array}{l}\text { Move to a position of touching - usually } \\
\text { atop (jump on, land on, fall on) }\end{array}$ & $\begin{array}{l}\text { Become attached (stick on, } \\
\text { clip on, tie on, put on) }\end{array}$ & $\begin{array}{l}\text { Continue (move on, hold on, } \\
\text { talk on) }\end{array}$ \\
\hline off & $\begin{array}{l}\text { Move to a position of not touching (jump } \\
\text { off, fly off, set off) }\end{array}$ & $\begin{array}{l}\text { Become unattached (take off, } \\
\text { come off, pull off) }\end{array}$ & \\
\hline back & $\begin{array}{l}\text { (1) Return to original position (go back, } \\
\text { come back, run back) } \\
\text { (2) Move backwards (step back) }\end{array}$ & $\begin{array}{l}\text { Return to original state (put } \\
\text { back, steal back, get back) }\end{array}$ & \\
\hline away & $\begin{array}{l}\text { Move to a far(ther) location (run away, } \\
\text { fly away, get away) }\end{array}$ & $\begin{array}{l}\text { Disappear } \\
\text { (fade away, wish away, wash } \\
\text { away) }\end{array}$ & \\
\hline after & $\begin{array}{l}\text { To follow or chase (run after, go after, } \\
\text { swim after) }\end{array}$ & & \\
\hline under (below) & $\begin{array}{l}\text { Move to a position lower than something } \\
\text { else (crawl under, walk under, go under) }\end{array}$ & & \\
\hline over & $\begin{array}{l}\text { Move to a position higher than something } \\
\text { else - or to traverse it (fly over, jump } \\
\text { over, go over) }\end{array}$ & $\begin{array}{l}\text { (1) Reverse } 180 \text { degrees on } \\
\text { a vertical axis (flip over, turn } \\
\text { over) } \\
\text { (2) Change from standing to } \\
\text { no longer standing (knock } \\
\text { over, push over) }\end{array}$ & \\
\hline across & $\begin{array}{l}\text { Move from one side of something to the } \\
\text { other side (walk across, swim across, } \\
\text { drive across) }\end{array}$ & & \\
\hline along & $\begin{array}{l}\text { Move on the same path as something } \\
\text { (drive along, float along, go along) }\end{array}$ & & $\begin{array}{l}\text { Do something together/at the } \\
\text { same time (sing along, read } \\
\text { along, play along) }\end{array}$ \\
\hline about/ around* & $\begin{array}{l}\text { Move in a circle or to various places } \\
\text { within (walk around, look around, go } \\
\text { around) }\end{array}$ & & \\
\hline through & $\begin{array}{l}\text { Move in one side and then out of the } \\
\text { other (drive through, pass through, go } \\
\text { through) }\end{array}$ & & \\
\hline apart & & $\begin{array}{l}\text { For a whole to become many } \\
\text { parts (come apart, pull apart, } \\
\text { rip apart) }\end{array}$ & \\
\hline together & & $\begin{array}{l}\text { For many pieces to become } \\
\text { one whole (put together, tie } \\
\text { together, come together) }\end{array}$ & \\
\hline
\end{tabular}

\footnotetext{
*About is more common in British PVs, and around is more common in American PVs (Liu, 2011; Garnier \& Schmitt, 2015)

using the theory of event conflation, there is a possibility that learners with L1s typologically different from English, such as Japanese, will benefit the most from it. Therefore, to test

the effectiveness of the list as an educational tool, I designed an experiment to see if L1 Japanese PV learners who utilize event conflation and the list of PV particles in Table 1 to
} 
study PVs improve their general PV proficiency more than L1 Japanese PV learners who utilize a whole-unit memorization strategy and a list of common PVs.

\section{METHOD}

\section{Materials}

The educational experiment reported in this paper utilized pre- and post-tests of phrasal verbs for quantitative data and a post-treatment survey for qualitative data. First, I created two pedagogically similar three-hour lessons to teach PVs, so that the learner outcomes of these lessons could be compared with minimized risk of teaching style being an influential factor. The two lessons were created with the same types of activities, worksheets, and materials, and were taught by the same instructor (see Appendix for the materials given to students and descriptions of the activities). The only major factor that changed between the lessons was whether PVs were introduced in parts, utilizing the list given in Table 1 and an explanation of event conflation, or as whole units. This resulted in the creation of one lesson with a focus on particle meanings based on the account of teaching PVs through event conflation detailed above (henceforth conflation method), and one lesson in which PVs were taught as whole units based on Garnier and Schmitt's (2015) PHaVE list (henceforth whole-unit method). Each lesson consisted of one hour of group work, one hour of lecture, and one hour of practice to promote retention. Both lessons had students guess meanings based on PVs that they knew and compare their answers with classmates, but in the conflation method lesson, students guessed the meanings of particles (see Appendix 1) whereas in the whole-unit lesson, students guessed various meanings of whole unit PVs (see Appendix 2). Lecture for both lessons consisted of the instructor correcting and amending student guesses, with the conflation method group also being instructed that various verbs could combine with the particles and would generally retain their original meanings, while the whole-unit method lesson students were instructed about the polysemy of PVs without explanation of event conflation. Both lessons had students participate in a charades game for 30 minutes and complete practice worksheets for 30 minutes, although students were given particles and verbs and asked to combine them into PVs for the game and worksheets in the conflation method lesson, whereas students were given PVs as whole units for the game and worksheets in the whole-unit method (see Appendix 3).

Pre- and post-tests were created to gauge participants' knowledge of PVs before and after their lessons. The pre- and post-tests both consisted of 60 multiple choicestyle fill in the blank questions, with five possible answers. 30 of the questions from each test came from the 100 most common PVs (as per Garnier \& Schmitt, 2015 - henceforth common $P V S$ ), with the meaning of the PV used for the question selected at random. The remaining 30 questions were created from PVs selected at random from the Corpus of Contemporary American English that did not fall in the top $100 \mathrm{PVs}$ (henceforth uncommon PVs). The difficulty of the tests was measured through the results of 18 L1 Japanese learners of English from Tohoku University (the same university as the main participants of this study), who took the tests simultaneously prior to the main study, and did not receive instruction or participate in the main study. The tests were calibrated by exchanging highly missed questions and rarely missed questions between them to create two tests of balanced difficulty. The results of the calibrated tests are shown in Table 2. Paired t-tests of these results revealed that neither the pre- nor post- test was significantly more difficult overall $(t(17)=-0.86, p=0.4 n s)$, for common PVs $(t(17)=-0.38, p=0.71 n s)$ or for uncommon PVs $(t(17)=-$ $0.61, p=0.55 n s)$.

A questionnaire was also created to gauge learners' attitudes towards the lessons. It consisted of five Likert-scale questions and one open-ended response question. Four of the Likert-scale questions asked participants to rate a statement from 1 (strongly disagree) to 5 (strongly agree) and the statements were: 'I enjoyed the lesson', 'I gained new knowledge from the lesson', 'The lesson was an appropriate way to teach PVs', and 'The lesson helped me'. The final Likert-scale question asked participants how they would rate the lesson overall from 1 (very bad) to 5 (very good). The open-ended response question simply asked the participants for any other general comments or suggestions they had regarding the lesson, and participants were asked to give at least one comment.

\section{Participants}

75 L1 Japanese learners of English who were students at Tohoku University were selected for participation in this study. They ranged from $1^{\text {st }}$ to $4^{\text {th }}$ year University students, and had all received a total of either 7 or 8 years of English education. This study was conducted after the end of the school year, during which time all participants were on academic break. Thus, no participants were participating in any other English study outside of the lessons given as part of this study. Participants had all recently taken the TOEFL-ITP test, and were asked to take the PV pre-test detailed in the previous section. The participants were then randomly divided into two groups: one that would receive the whole-unit method lesson and one that would receive the conflation method lesson. The data for the participants is shown in Table 3 , and unpaired t-tests revealed that there was no significant differences in participants' TOEFL scores $(t(74)=0.28, p=0.39$ $n s)$, overall pre-test scores $(t(74)=-0.44, p=0.33 n s)$, pre-test common PV scores $(t(74)=-0.01, p=0.49 n s)$ or pre-test uncommon PV scores $(t(74)=0.79, p=0.22 n s)$.

Table 2. Results of the calibrated PV pre- and post-tests

\begin{tabular}{lcc}
\hline Category & $\begin{array}{c}\text { Average pre-test } \\
\text { score (SD) }\end{array}$ & $\begin{array}{c}\text { Average post-test } \\
\text { score (SD) }\end{array}$ \\
\hline Overall & $0.58(0.13) \pm 0.057$ & $0.57(0.1) \pm 0.044$ \\
Common PVs & $0.6(0.13) \pm 0.057$ & $0.6(0.12) \pm 0.053$ \\
Uncommon PVs & $0.55(0.15) \pm 0.066$ & $0.53(0.1) \pm 0.044$ \\
\hline
\end{tabular}

*Confidence intervals calculated at the $95 \%$ confidence level 
Table 3. Participant data

\begin{tabular}{lccccc}
\hline $\begin{array}{l}\text { Lesson } \\
\text { Style }\end{array}$ & N & $\begin{array}{c}\text { TOEFL Score } \\
\text { (SD) }\end{array}$ & $\begin{array}{c}\text { Pre-test Average } \\
(\text { SD) }\end{array}$ & $\begin{array}{c}\text { Pre-test Common } \\
\text { PV Average (SD) }\end{array}$ & $\begin{array}{c}\text { Pre-test Uncommon } \\
\text { PV Average (SD) }\end{array}$ \\
\hline $\begin{array}{l}\text { Whole-unit } \\
\begin{array}{l}\text { Method } \\
\text { Conflation }\end{array}\end{array}$ & 36 & $514.6(49.2) \pm 16$ & $0.65(0.12) \pm 0.039$ & $0.65(0.14) \pm 0.046$ & $0.66(0.12) \pm 0.039$ \\
Method & 39 & $517.6(39.1) \pm 12$ & $0.64(0.1) \pm 0.031$ & $0.65(0.11) \pm 0.035$ & $0.64(0.11) \pm 0.035$ \\
\hline
\end{tabular}

*Confidence intervals calculated at the $95 \%$ confidence level

\section{Procedure}

Participants in each group were taught their corresponding lesson by the same instructor, exactly one week after implementation of the pre-test. All participants were given their lessons in two 90 minute blocks, with a 10 minute break between blocks. The instructor took care that none of the $60 \mathrm{PVs}$ that were on the post-test would appear in the conflation method lesson, and the games, practice problems and instruction were created in order to ensure learners of the conflation method lesson would not encounter any of them during their study session. In contrast, learners in the whole-unit method lesson were taught all 100 common PVs, and thus, participants encountered 30 of the PVs that would appear on the post-test in their lesson. Participants were then given the post-test 24 hours after instruction, and the questionnaire thereafter.

Learner improvement was evaluated within groups by comparing pre- and post-test scores with paired t-tests. Twoway ANOVA tests with one independent variable (lesson style) and one dependent variable (time; i.e. pre- and posttest scores) were used to check for significant interaction between lesson style and improvement. These tests were chosen because the sample sizes were adequately large and the collected data were found to be parabolic. Cohen's D was calculated as a measure of effect size. Confidence intervals were calculated at the $95 \%$ confidence level. Learner's attitudes towards the lessons were analyzed qualitatively based on their answers to the questionnaire.

\section{RESULTS}

\section{Analysis of Quantitative Data}

The results of the pre- and post-test scores for participants in the conflation method lesson group are shown in Figure 1, and the same results for participants in the whole-unit method lesson group are shown in Figure 2.

A paired t-test of the pre-test $(M=0.64, S D=0.1, \pm 0.031)$ and post-test $(M=0.73, S D=0.07, \pm 0.022)$ scores of participants that received the conflation method lesson indicated that they improved significantly; $t(38)=6.96, p<0.001, d=1.6$. However, a comparison of the pre-test $(M=0.65, S D=0.12$, $\pm 0.039)$ and post-test $(M=0.66, S D=0.09, \pm 0.029)$ scores of participants that received the whole-unit method lesson did not yield a significant difference; $t(35)=0.74, p=0.46 n s$. Furthermore, a two-way ANOVA indicated a significant interaction between lesson style and overall improvement on the PV test; $F(1,149)>99, p<0.001, d=0.95$.

Similar statistical tests were performed on participant's scores for both common PVs and uncommon PVs. A paired

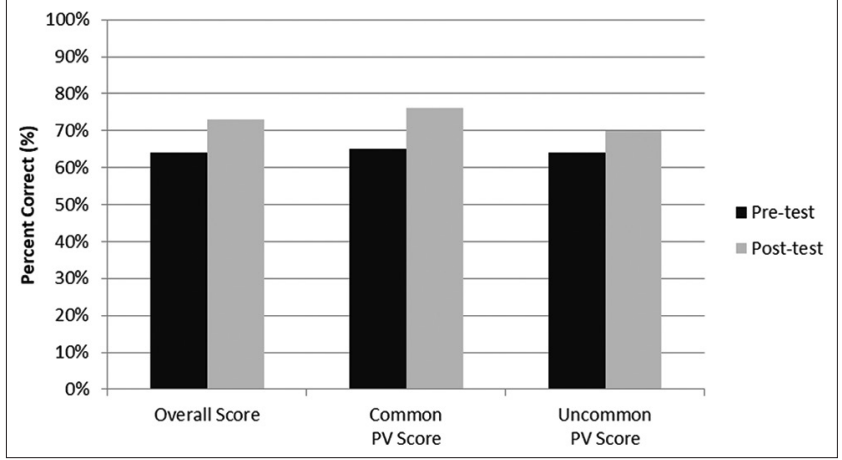

Figure 1. Conflation method lesson group's pre- and post-test scores

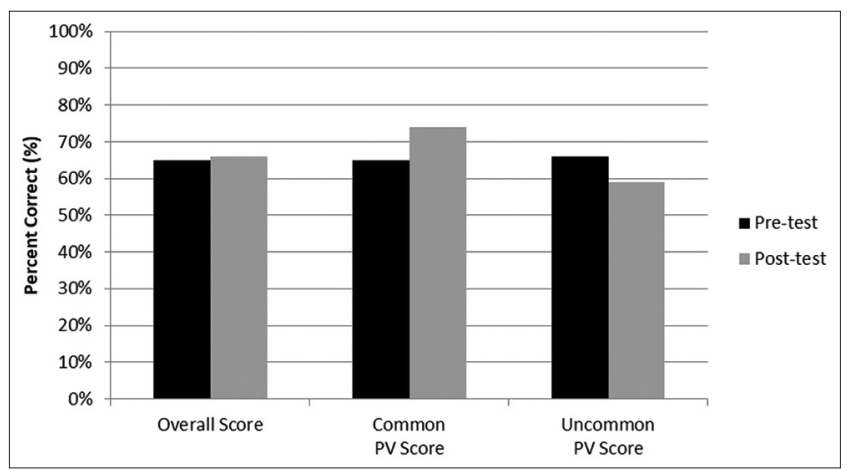

Figure 2. Whole-unit method lesson group's pre- and post-test scores

t-test of the pre-test $(M=0.65, S D=0.11, \pm 0.035)$ and post-test $(M=0.76, S D=0.09, \pm 0.028)$ common PV scores of participants that received the conflation method lesson indicated that they improved significantly; $t(38)=6.27, p<0.001$, $d=1.4$. A comparison of the pre-test $(M=0.65, S D=0.14$, $\pm 0.046)$ and post-test $(M=0.74, S D=0.09, \pm 0.029)$ common PV scores of participants that received the whole-unit method lesson also yielded a significant difference; $t(35)=4.06$, $p<0.001, d=0.96$. No significant interaction was found between lesson style and improvement on common PVs; F(1, 149) $=0.00, p=1$.

With regards to uncommon PVs, paired t-tests of the pre-test $(M=0.64, S D=0.11, \pm 0.035)$ and post-test $(M=0.7$, $S D=0.08, \pm 0.025)$ scores of participants in the conflation method lesson group indicated that they improved significantly; $t(38)=3.71, p<0.001, d=0.84$. However, a comparison of the pre-test $(M=0.66, S D=0.12, \pm 0.039)$ and post-test $(M=0.59, S D=0.11, \pm 0.036)$ scores of participants in the whole-unit method lesson group seemed to indicate a significant decrease in uncommon PV knowledge; $t(35)=-4.58$, 
$p<0.001, d=-1.08$. A significant interaction between lesson style and improvement on uncommon PVs was found; $F$ (1, 149) $>99, p<0.001, d=1.34$.

\subsection{Analysis of Qualitative Data}

The results of the Likert-scale questions given to participants are represented in Figure 3. Strongly agree or very good is noted as a score of five in Figure 3, and strongly disagree or very bad is noted as a score of one.

There did not seem to be a large difference in whether or not participants in each group enjoyed the lesson (question 1; $M=4.41 S D=0.55$ for conflation method, $M=4.39 S D=0.6$ for whole-unit method). However, much larger differences were found in other opinions. Participants in the conflation method group scored their lesson higher than participants in the whole-unit group with regards to feeling that they had gained knowledge $(M=4.67, S D=0.48$ vs $M=4.17$, $S D=0.56)$, the lesson being helpful $(M=4.64, S D=0.49$ vs $M=4.19, S D=0.52$ ) and their overall rating of the lesson $(M=4.56, S D=0.5$ vs $M=4.03, S D=0.45)$. However, the most pronounced difference in opinion occurred with regard to whether or not the learners found their lessons to be an appropriate method for teaching PVs, with participants in the conflation method group scoring their lesson 4.59 on average $(S D=0.5)$ while participants in the whole-unit method group scored their lesson 3.61 on average $(S D=0.77)$.

With regards to the open-ended response style question, of the 39 participants in the conflation method group, $26(67 \%)$ made comments indicating that the relation between event conflation and PVs was new information to them and learning about it helped them to remember and guess the meanings of PVs. Representative responses include "breaking the [particles] into 'motion', 'change', etc. made it easy to understand that particles have several different meanings" and "I had learned [the] meanings of prepositions before, but never how they can combine with verbs to make PVs - this was easy to understand and helpful". Furthermore, 10 participants $(26 \%)$ in the conflation method group mentioned that the lesson made PVs easier to remember. Representative comments include "I got a better image for PVs and it made them easier to remember" and "I had only ever studied PVs as a one unit set - this way was better and helped make them

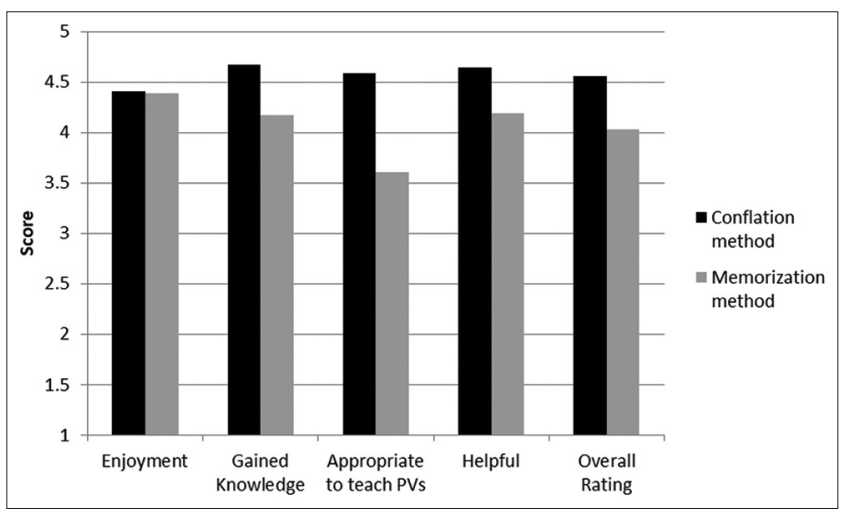

Figure 3. Results of Likert-scale questions in post-instruction questionnaire easier to remember". Conversely, of the 36 participants in the whole-unit method group, 9 (24\%) commented that they wished they had some sort of explanation about how PVs are formed. Representative comments include "I wanted to know the meanings of the individual parts of PVs" and "there was no detailed explanation of how PVs were put together, so I couldn't learn them so well". Furthermore, 7 participants (19\%) of this group indicated that it was difficult to remember the PVs - a comment that was not received at all from members of the conflation method group. Representative comments include "there wasn't enough time, so I couldn't remember the PVs so well" and "the class was fun, but having so many PVs is hard to remember".

\section{DISCUSSION}

The results of this study indicate that it is possible to make a list of PV particles and their meanings based on the theory of event conflation and that the list can be used to effectively teach PVs to L1 Japanese learners of English. First, the list presented in Table 1 was created by grouping particle meanings according to the theory of event conflation, which allowed it to be concise enough to contain only three categories, but comprehensive enough to cover approximately $95 \%$ of PV meanings. Second, both the quantitative and qualitative data taken from the educational experiment reported in Section 5 suggest that the lesson was helpful to L1 Japanese learners of English. The quantitative data showed that participants in the conflation method group outperformed those in the whole-unit method group significantly in overall PV knowledge based on their post-tests, although they demonstrated equivalent PV knowledge on the pre-tests. These results seem to be congruent with previous studies such as Side (1990) and Lee (2012) that suggest focusing on particle meanings can be a more efficient way to study PVs. The qualitative data corroborated these results, with learners in the conflation method group, scoring their lesson as having been more helpful and a more appropriate way of learning PVs than the learners in the whole-unit method group. Furthermore, the fact that learners in both groups spent the same amount of time studying PVs suggests that utilizing the list given in Table 1 to teach PVs through event conflation, as described in this paper, is more efficient (more gains in PV knowledge were made by the conflation method group for the same amount of study). This was further supported by the responses in the free answer section of the survey by the learners in the whole-unit group who expressed that they felt there wasn't enough time to remember all of the PVs and that there were too many to try to remember. However, this result is not particularly surprising, because the particle list in Table 1 requires learners to remember far fewer meaning tokens than a list of PVs.

It should be noted that although both groups' scores for common PVs improved about the same amount, the conflation method group far out-performed their whole-unit method counterparts with regards to uncommon PVs. It is not surprising that learners in the whole-unit group improved their scores on the common PVs because they studied these PVs specifically and were then tested on them in the post- 
test. However, it is interesting that the event conflation group improved on common PVs at about the same amount. Since both Yasuda (2010) and Lee (2012) suggested that use of cognitive linguistics, such as metaphoric extension, aid in the memorization of PVs, and since the conflation method also made use of metaphoric extension, it may be that learners benefitted from this knowledge and were able to improve their common PV knowledge to a similar amount as the whole-unit group. However, as suggested in Section $3,95 \%$ of the two most common meanings for the top 20 PVs are covered by event conflation, and so perhaps learners in the event conflation group were not hindered much by the fact that they did not study any of these meanings explicitly. The fact that the conflation method group outperformed the whole-unit method group on uncommon PVs is congruent with Side (1990), who suggested that learning common meaning senses of particles could aid learners in being able to conjecture the meaning of novel PVs. Learners in the whole-unit method group were not explicitly given any strategies to guess the meanings of novel PVs, but learners in the event conflation group were; which seems to have made a large difference and empirically supports the claims of both Side (1990) and Sections 2 and 3 of this paper. This result was corroborated by the qualitative data, as learners in the conflation method group noted in the free response section that the lesson helped them to remember PVs more easily and guess their meanings. These results suggest that while learning PVs as whole-units can be effective (i.e. ability improves for tokens studied), learning through event conflation and the particle list given in Table 1 is not only equally effective for learning common PVs, it is it also aides in the ability to conjecture the meanings of novel PVs. This results in greater gains in overall PV knowledge for the same amount of study time.

While the results of this study are promising, it should be noted here that it does have some limitations. For example, the PV pre- and post-tests were designed to be equally difficult for L1 Japanese learners at Tohoku University, and were calibrated with non-participants. This allowed me to ensure that the questions for both the common and uncommon PVs were balanced for difficulty on these tests, but it does not give any indication about which PVs participants already knew on the post-test. However, given the low pre-test scores and the fact that both groups of learners improved from pre- to post-test in at least one area while the non-participant test collaborators didn't suggests that it is reasonable to assume that though the participants may have known some of the PVs on the post-test, they likely did not know any more on the post-test than they did on the pre-test. Therefore, it is reasonable to assume that improvement shown from the pretest to the post-test indicated improved knowledge of PVs (or at least improved ability to conjecture their meanings). Another limitation of this research is that it had very little qualitative data. Though the quantitative data was sufficient to show a difference in how much learners improved their PV knowledge between the two groups, and the qualitative data could help corroborate the results, taking more qualitative data from more in-depth surveys or reflection papers could help to pinpoint the exact reasons why the learners felt the lessons were helpful. Finally, this study was conducted on L1 Japanese learners of English, for whom motion and change expressions in English are known to be particularly challenging (Spring \& Horie, 2013; Spring, 2015; Inagaki, 2002; etc.). Therefore, it is unclear how beneficial these materials would be for ESL learners with other native languages, particularly with L1s of the same type as English (i.e. satellite-framed languages). Thus, future studies should be done to verify the results of this paper with more qualitative data, other PV testing methods and with ESL learners with various other L1s (especially with other verb-framed languages such as French, Spanish and Korean).

\section{CONCLUSION}

This paper showed that it is possible to create a comprehensive, yet concise list of PV particles and their meanings by utilizing PV corpus studies and the cognitive linguistic theory of event conflation. Furthermore, it showed that this list can be used to teach PVs to L1 Japanese learners of English more effectively than by teaching PVs as whole units through a PV list. It is therefore able to suggest that the materials shown in Appendix 1 can be an effective and innovative tool for PV instruction. Hopefully the results of this study and the list provided herein can aid other EFL/ESL educators who are teaching PVs and can benefit researchers in the future as well.

\section{NOTES}

Note 1. Some linguists make a distinction between true PVs and 'prepositional' verbs, but this paper refers to both as PVs following the research of Garnier and Schmitt (2015), Liu (2011), etc.

Note 2. For a more complete overview of the research in each of these sections, see Jahedi and Mukundan (2015), a review of recent $\mathrm{PV}$ research.

Note 3. Talmy (2000) defines a satellite as "the grammatical category of any constituent other than a noun-phrase or prepositional-phrase complement that is in a sister relation to the verb root" (p. 102), which includes prepositions (Talmy, 2009), particles and adjectives.

Note 4: The two most common meanings of the first 20 verbs in Garnier and Schmitt's (2015) were checked against the particle list in Table 1, and all meanings were found to be contained in the table except for the meaning of 'to occur' for come up, and the meaning of 'to place or rank (as in a race)' for come in. Thus, 38 of the most commonly occurring $40 \mathrm{PV}$ meanings were found to be explainable with the list in Table 1, and the approximation of $95 \%$ was reached.

\section{REFERENCES}

Boers, F. (2000). Metaphor awareness and vocabulary retention. Applied Linguistics, 21, 553-571. https://doi. org/10.1093/applin/21.4.553

Gardner, D. \& Davies, M. (2007). Pointing out frequent PVs: A corpus based analysis. TESOL Quarterly, 41(2), 
339-359. https://doi.org/10.1002/j.1545-7249.2007. tb00062.x

Garnier, M. \& Schmitt, N. (2015). The PHaVE List: A pedagogical list of PVs and their most frequent meaning senses. Language Teaching Research, 19 (6), 645-666. https://doi.org/10.1177/1362168814559798

Inagaki, S. (2002). Motion verbs with locational/directional PPs in English and Japanese. Canadian Journal of Linguistics/Revue canadienne de linguistique, 47, 187-234. https://doi.org/10.1075/z.133.04ina

Jahedi, M. \& Mukundan, J. (2015). A review on studies of phrasal verb constructions in ESL context. Advances in Language and Literary Studies, 6(1), 157-162. https:// doi.org/10.7575/aiac.alls.v.6n.1p.157

Lee, H. (2012). Concept-based approach to second language teaching and learning: Cognitive linguistics-inspired instruction of English phrasal verbs: $\mathrm{PhD}$ Thesis, Pennsylvania State University, USA.

Liao, Y. \& Fukuya Y.J. (2004). Avoidance of phrasal verbs: The case of Chinese learners of English. Language Learning, 54: 193-226. doi:10.1111/j.14679922.2004.00254.x

Liu, D. (2011). The most frequently used English phrasal verbs in American and British English: A multicorpus examination. TESOL Quarterly, 45(4), 661-688. https:// doi.org/10.5054/tq.2011.247707

Side, R. (1990). PVs: Sorting them out. ELT Journal, 44(2), 144-152. https://doi.org/10.1093/elt/44.2.144
Spring, R. \& Horie, K. (2013). How cognitive typology affects second language acquisition: A study of Japanese and Chinese learners of English. Cognitive Linguistics, 24 (4), 689-710. https://doi.org/10.1515/cog-2013-0024

Spring, R. (2015). Jisho fure-mu no gengo ruikei to dainigengo shutoku: Ido to joutai henka no hyogen wo megutte [The linguistic typology of event framing and SLA: Looking at motion and change of state expressions]. In N. Ono and Y. Yumoto (eds.) Goi imiron no aratana kanosei wo sagutte [Inquiries into new possibilities of lexical semantics] (pp. 408-431). Tokyo: Kaitakusha. ISBN: 9784758922210

Talmy, L. (1985). Lexicalization patterns. Semantic structure in lexical form. In: Shopen T (ed) Language typology and syntactic description (Vol. 3, pp.36-149). Cambridge: CUP. https://doi.org/10.1017/cbo9780511618437.002

Talmy, L. (2000). Toward a cognitive semantics (2): Typology and process in concept structuring. Cambridge, MA: MIT Press. ISBN: 0262700972

Talmy, L. (2009). Main verb properties and equipollent framing. Crosslinguistic approaches to the psychology of language. In: Guo J, Lieven E, Budwig N, Ervin-Tripp S, Nakamura K, and Özçalışkan, Ş. (eds) Research in the tradition of Dan Isaac Slobin (pp.389-402). New York and London: Psychology Press. ISBN: 9780805859997

Yasuda, S. (2010). Learning phrasal verbs through conceptual metaphors: A case study of Japanese EFL learners. TESOL Quarterly, 44(2), 250-273. https://doi. org/10.5054/tq.2010.219945

\section{APPENDIX}

\section{Appendix 1 - Instructional Materials for Conflation Method Group}

Students were initially given the list of 17 particles with the meanings blank. After guessing meanings, the instructor provided the examples and explanations shown below. The instructor suggested that verbs retained their basic meanings, as did particles, and thus jump up meant 'to move from low to high by jumping', while fly up meant 'to move from low to high by flying'

\begin{tabular}{|c|c|c|c|}
\hline Word & Motion Meaning & Change Meaning & Aspect Meaning \\
\hline \multirow[t]{3}{*}{ up } & Moving from low to high** & Become good/better/more* & Complete / $100 \% * *$ \\
\hline & & $\begin{array}{l}\text { He went up in the company. } \\
\text { go up, come up, shoot up }\end{array}$ & clean up, dress up, charge up \\
\hline & $\begin{array}{l}\text { The circle moves up. } \\
\text { jump up, stand up, fly up }\end{array}$ & & \\
\hline \multirow[t]{3}{*}{ down } & Moving from a high to low $* *$ & Become bad/worse/less* & Finish, Achieve** \\
\hline & & $\begin{array}{l}\text { The player let his team down. } \\
\text { let down, come down, fall down }\end{array}$ & break down, hunt down, calm down \\
\hline & $\begin{array}{l}\text { The circle moves down. } \\
\text { sit down, lay down, fall down }\end{array}$ & & \\
\hline
\end{tabular}


Appendix 1. (Continued)

\begin{tabular}{|c|c|c|c|}
\hline Word & Motion Meaning & Change Meaning & Aspect Meaning \\
\hline \multirow[t]{2}{*}{ in } & Enter & & \\
\hline & $\begin{array}{l}\text { The circle moves in the square. } \\
\text { go in, come in, walk in }\end{array}$ & & \\
\hline \multirow[t]{2}{*}{ out } & $\begin{array}{l}\text { Exit, move outside (*of } \\
\text { something) }\end{array}$ & $\begin{array}{l}\text { (1) Appear } \\
\text { (2) Disappear }\end{array}$ & Completely** \\
\hline & $\begin{array}{l}\text { The circle moves out (of the } \\
\text { square). } \\
\text { go out, walk out, fly out }\end{array}$ & $\begin{array}{l}\text { The ball came out (from hiding) } \\
\text { The ball went out (from sight) } \\
\text { come out, go out, turn out }\end{array}$ & find out, figure out, fill out \\
\hline \multirow[t]{2}{*}{ on } & $\begin{array}{l}\text { Moving from not touching place } \\
\text { to touching (usually higher)*** }\end{array}$ & Become touching / attached $* *$ & Continue \\
\hline & $\begin{array}{l}\text { The circle moves on the square. } \\
\text { jump on, land on, fall on }\end{array}$ & $\begin{array}{l}\text { He stuck the circle on the square. } \\
\text { put on, clip on, stick on }\end{array}$ & walk on, keep on, hold on \\
\hline \multirow[t]{2}{*}{ off } & & $\begin{array}{l}\text { Become not-touching / } \\
\text { unattached }{ }^{* *} \text { (*of something) }\end{array}$ & \\
\hline & & $\begin{array}{l}\text { The circle came off (of the } \\
\text { square). } \\
\text { take off, come off, pull off }\end{array}$ & \\
\hline \multirow[t]{2}{*}{ back } & $\begin{array}{l}\text { (1) Moving backward } \\
\text { (2) Return to original position }\end{array}$ & Return to original state & \\
\hline & $\begin{array}{l}\text { The circle moves back. } \\
\text { step back, go back, run back }\end{array}$ & $\begin{array}{l}\text { His arm healed back. } \\
\text { get back, put back, steal back }\end{array}$ & \\
\hline \multirow[t]{2}{*}{ away } & $\begin{array}{l}\text { Moving farther (*from } \\
\text { something) }\end{array}$ & Disappear & \\
\hline & $\begin{array}{l}\text { The circle moves away (from the } \\
\text { square). } \\
\text { run away, go away, fly away }\end{array}$ & $\begin{array}{l}\text { The circle went away. } \\
\text { go away, blow away, wish away }\end{array}$ & \\
\hline
\end{tabular}


Appendix 1. (Continued)

\begin{tabular}{ll}
\hline Word & Motion Meaning \\
\hline after & Following something \\
under \\
(below)
\end{tabular}

The circle moves over the square. fly over, jump over, go over

across

Moving from one side of something to the other side

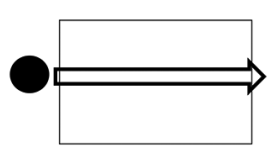

The circle moves across the box. go across, walk across, swim across

along

Moving on the path of something

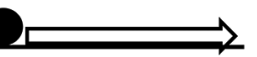

The circle moves along the line. walk along, go along, float along

apart

together
Change Meaning

Aspect Meaning

(1) Reverse $180^{\circ}$ vertically

(2) Off of the base

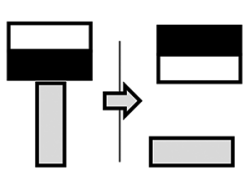

The rectangle turned over. turn over, flip over, fall over

Do something at the same time (* with something/ someone else)

read along, play along
Become many pieces**

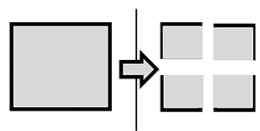

The square came apart.

fall apart, come apart, pull apart

Become one unit**

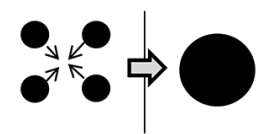

The circles were pushed together. put together, come together, tie together 
Appendix 1. (Continued)

\begin{tabular}{l} 
Word Motion Meaning Aspect Meaning \\
\hline around \\
(about)
\end{tabular}

\section{Appendix 2 - Instructional Materials for Whole-unit Method Group}

Students were initially given the list of 100 PVs with the meanings blank. After guessing meanings and sharing with their groups, the instructor amended their guesses with any of the meanings shown below that were missing. The instructor suggested some PVs had similar meanings because they had similar parts (such as go in and come in), but did not provide an explanation of event conflation, the meanings of particles themselves, or how verbs and particles combined to form new meanings. Explanation of metaphorical extension of meanings was also offered where applicable (e.g. go back and come back)

\begin{tabular}{|c|c|c|c|}
\hline Phrasal Verb & Meaning 1 & Meaning 2 & Meaning 3 \\
\hline 1. Go on & Move onto or get aboard & Continue & Occur \\
\hline 2. Pick up & To put into one's hand & To improve or increase & \\
\hline 3. Come back & To return to a place & To return to a state & \\
\hline 4. Come up & To rise & To occur & For a problem to arise \\
\hline 5. Go back & To return & To return to a state & \\
\hline 6. Find out & Discover knowledge & & \\
\hline 7. Come out & Exit & Be released or appear & \\
\hline 8. Go out & Exit & Disappear & \\
\hline 9. Point out & Indicate & & \\
\hline 10. Grow up & Progress towards maturity & Develop & \\
\hline 11. Set up & Make upright & Build or construct & Plan \\
\hline 12. Turn out & Turn off lights/power & Show up & Make to leave \\
\hline 13. Get out & Exit & To become known & \\
\hline 14. Come in & Enter & Place or rank (as in a race) & \\
\hline 15. Take on & To be responsible for & To acquire & \\
\hline 16. Give up & To forfeit & To stop or desist & \\
\hline 17. Make up & Consist of & Create a story or falsehood & \\
\hline 18. End up & Arrive at some state & & \\
\hline 19. Get back & $\begin{array}{l}\text { Have something returned } \\
\text { to you }\end{array}$ & Take revenge on someone & \\
\hline
\end{tabular}


Appendix 2. (Continued)

\begin{tabular}{|c|c|c|c|}
\hline Phrasal Verb & Meaning 1 & Meaning 2 & Meaning 3 \\
\hline 20. Look up & To look upwards & To research & \\
\hline 21. Figure out & $\begin{array}{l}\text { To gain knowledge by your } \\
\text { own accord }\end{array}$ & To calculate & \\
\hline 22. Sit down & To move to a seated position & & \\
\hline 23. Get up & To stand up & Awaken & \\
\hline 24. Take out & To remove & $\begin{array}{l}\text { To accompany someone on } \\
\text { an outing }\end{array}$ & \\
\hline 25. Come on & To start to happen or work & Encouraging words & For an illness to begin \\
\hline 26. Go down & To descend & To reduce in value/amount & \\
\hline 27. Show up & To arrive somewhere & To appear or be seen & \\
\hline 28. Take off & To remove & To leave the area & $\begin{array}{l}\text { To suddenly become } \\
\text { popular or successful }\end{array}$ \\
\hline 29. Work out & To exercise & $\begin{array}{l}\text { To develop with a certain } \\
\text { ending }\end{array}$ & $\begin{array}{l}\text { To be the result of a } \\
\text { calculation }\end{array}$ \\
\hline 30. Stand up & To upright yourself & To fight for something & \\
\hline 31. Come down & To fall or descend & To become less & \\
\hline 32. Go ahead & Proceed & Start to do something & \\
\hline 33. Go up & To ascend & $\begin{array}{l}\text { To suddenly explode or } \\
\text { burn }\end{array}$ & To rise or be built \\
\hline 34. Look back & To look behind oneself & To think of the past & \\
\hline 35. Wake up & To awaken & To realize & \\
\hline 36. Carry out & To take outside & To execute or do & \\
\hline 37. Take over & $\begin{array}{l}\text { To gain control of } \\
\text { something }\end{array}$ & $\begin{array}{l}\text { To replace someone in a } \\
\text { task }\end{array}$ & \\
\hline 38. Hold up & To be delayed & $\begin{array}{l}\text { To remain strong or } \\
\text { successful }\end{array}$ & To rob \\
\hline 39. Pull out & To remove & To stop being involved & \\
\hline 40. Turn around & To spin 180 degrees & To change courses & \\
\hline 41. Take up & Lift & Begin doing something & \\
\hline 42. Look down & Look downwards & $\begin{array}{l}\text { To think yourself better } \\
\text { than another }\end{array}$ & \\
\hline 43. Put up & $\begin{array}{l}\text { To accept or continue } \\
\text { something unpleasant }\end{array}$ & Let someone stay & \\
\hline 44. Bring back & $\begin{array}{l}\text { Return from somewhere } \\
\text { with something }\end{array}$ & $\begin{array}{l}\text { To do something that was } \\
\text { done in the past }\end{array}$ & \\
\hline 45. Bring up & To raise & $\begin{array}{l}\text { To begin talking about a } \\
\text { subject }\end{array}$ & \\
\hline 46. Look out & To be careful & To watch for danger & \\
\hline 47. Bring in & To take in from outside & To earn & \\
\hline 48. Open up & To open a door (etc.) & To talk about your feelings & \\
\hline 49. Check out & To check facts (etc.) & To pay and leave & \\
\hline 50. Move on & To continue & $\begin{array}{l}\text { To start a new job or } \\
\text { activity }\end{array}$ & \\
\hline 51. Put out & To make to leave & produce & \\
\hline 52. Look around & $\begin{array}{l}\text { To look at the things in a } \\
\text { place or area }\end{array}$ & & \\
\hline 53. Catch up & $\begin{array}{l}\text { Reach the same place, } \\
\text { speed, quality (etc.) }\end{array}$ & To learn the latest news & \\
\hline 54. Go in & Enter & & \\
\hline
\end{tabular}


Appendix 2. (Continued)

\begin{tabular}{|c|c|c|c|}
\hline Phrasal Verb & Meaning 1 & Meaning 2 & Meaning 3 \\
\hline 55. Break down & To stop working & To become smaller parts & $\begin{array}{l}\text { To become emotionally } \\
\text { unstable }\end{array}$ \\
\hline 56. Get off & To leave a place & To finish work (etc.) & \\
\hline 57. Keep up & Maintain a pace (etc.) & $\begin{array}{l}\text { To have the knowledge of } \\
\text { something recent }\end{array}$ & \\
\hline 58. Put down & To release downwards & To insult & \\
\hline 59. Reach out & Extend arm/hand/etc. & Offer help to someone & \\
\hline 60. Go off & To leave & To happen in a way & To explode, ring, etc. \\
\hline 61. Cut off & To remove by cutting & To stop (especially a flow) & \\
\hline 62. Turn back & $\begin{array}{l}\text { To return to the direction } \\
\text { one came from }\end{array}$ & & \\
\hline 63. Pull up & $\begin{array}{l}\text { To raise something with a } \\
\text { pull }\end{array}$ & To get information & \\
\hline 64. Set out & $\begin{array}{l}\text { To start an activity or } \\
\text { journey }\end{array}$ & To put in a visible position & \\
\hline 65. Clean up & To make something clean & & \\
\hline 66. Shut down & To stop operating & & \\
\hline 67. Turn over & To flip 180 degrees & To give control to another & \\
\hline 68. Slow down & To decrease speed & & \\
\hline 69. Wind up & $\begin{array}{l}\text { To end in a specific } \\
\text { situation }\end{array}$ & $\begin{array}{l}\text { To turn something to give } \\
\text { it power }\end{array}$ & \\
\hline 70. Turn up & To increase (esp. volume) & To show up or arrive & \\
\hline 71. Line up & To make a line & & \\
\hline 72. Take back & $\begin{array}{l}\text { To get something again that } \\
\text { was originally yours }\end{array}$ & $\begin{array}{l}\text { To admit what you said was } \\
\text { wrong }\end{array}$ & \\
\hline 73. Lay out & $\begin{array}{l}\text { To put something in a } \\
\text { visible position }\end{array}$ & To design & \\
\hline 74. Go over & To review & To move above something & \\
\hline 75. Hang up & To end a phone call & $\begin{array}{l}\text { To put something in a high, } \\
\text { hanging position }\end{array}$ & \\
\hline 76. Go through & $\begin{array}{l}\text { Move in one end, out of the } \\
\text { other }\end{array}$ & Experience & \\
\hline 77. Hold on & To wait & To manage or survive & \\
\hline 78. Pay off & $\begin{array}{l}\text { To pay a loan (etc.) } \\
\text { completely }\end{array}$ & To result in success & \\
\hline 79. Hold out & $\begin{array}{l}\text { Continue in a difficult } \\
\text { situation }\end{array}$ & $\begin{array}{l}\text { To not give information to } \\
\text { others }\end{array}$ & To extend outwards \\
\hline 80. Break up & $\begin{array}{l}\text { Breaking or dividing into } \\
\text { smaller pieces }\end{array}$ & To end a relationship & \\
\hline 81. Bring out & Take something outwards & $\begin{array}{l}\text { To make a detail or quality } \\
\text { noticeable }\end{array}$ & \\
\hline 82. Pull back & To pull backwards & $\begin{array}{l}\text { To stop supporting or doing } \\
\text { something }\end{array}$ & \\
\hline 83. Hang on & To wait & $\begin{array}{l}\text { To continue to hold } \\
\text { something }\end{array}$ & \\
\hline 84. Build up & To increase & To create or construct & \\
\hline 85. Throw out & Get rid of & Reject or refuse something & \\
\hline 86. Hang out & $\begin{array}{l}\text { To spend time with } \\
\text { someone }\end{array}$ & & \\
\hline 87. Put on & To wear & To place on top of & \\
\hline
\end{tabular}


Appendix 2. (Continued)

\begin{tabular}{|c|c|c|c|}
\hline Phrasal Verb & Meaning 1 & Meaning 2 & Meaning 3 \\
\hline 88. Get down & Move downwards & & \\
\hline 89. Come over & $\begin{array}{l}\text { To come to someone's } \\
\text { location }\end{array}$ & & \\
\hline 90. Move in & Change locations or abodes & Enter & \\
\hline 91. Start out & $\begin{array}{l}\text { Begin something such as a } \\
\text { job or part of life }\end{array}$ & & \\
\hline 92. Call out & Summon to a place & $\begin{array}{l}\text { Recognize or appoint } \\
\text { someone }\end{array}$ & \\
\hline 93. Sit up & To sit with a straight back & & \\
\hline 94. Turn down & $\begin{array}{l}\text { Make lower (especially } \\
\text { volume) }\end{array}$ & Reject & \\
\hline 95. Back up & Move backwards & Support & \\
\hline 96. Put back & $\begin{array}{l}\text { Return something to its } \\
\text { original location }\end{array}$ & $\begin{array}{l}\text { Return something to its } \\
\text { original state }\end{array}$ & \\
\hline 97. Send out & $\begin{array}{l}\text { To make something move } \\
\text { so that it spreads from the } \\
\text { original point }\end{array}$ & & \\
\hline 98. Get in & To enter & To arrive & \\
\hline 99. Blow up & To explode & To argue & To fill with air \\
\hline 100. Carry on & To continue to do something & $\begin{array}{l}\text { To bring on to something } \\
\text { else }\end{array}$ & $\begin{array}{l}\text { To behave in an } \\
\text { uncontrolled or excited } \\
\text { manner }\end{array}$ \\
\hline
\end{tabular}

\section{APPENDIX 3 - DESCRIPTION OF CHARADES GAMES FOR BOTH GROUPS}

Students in the conflation method lesson were asked to play a gesture game by having one student in a group become and actor and choose one of the particles that contains a motion meaning, and one of a set of verbs (walk, jump, swim, jog, fly) and then act out what the meaning would become. Other students were asked to guess the phrasal verb the actor had thought of by guessing which verb and which particle the actor had selected. The game was performed for motion meanings for 15 minutes and for change meanings for 15 minutes with actors selecting one of the particles that contains a change meaning, and one of a set of verbs (bite, fall, burn, break, cut).

Students in the whole-unit method lesson were asked to play a gesture game in which one student in a group became an actor and acted out one of the meanings of a set of 10 phrasal verbs (pre-selected by the students) with other group members guessing which phrasal verb the actor had selected. This was repeated with students changing groups multiple times for 30 minutes. 